\title{
ON THE ISSUE OF DETERMINING THE CIVIL-LAW STATUS OF SERVICEMEN
}

\section{Kryvenko Yu. V.}

\section{INTRODUCTION}

Modern society faces a number of complex social and political problems, including the realization of military reform and building a legal country are prime. The recognition and promotion of universal values is a prerequisite for the establishment and functioning of the rule of law. Among the generally recognized legal values that exist in modern civilized society, the central place is occupied by those who determine the status of a person, regulate and protect his rights and freedoms.

National defense is one of the most important functions of the state and military service - the honorable duty of citizens. Changes in the domestic politics and international situation of Ukraine have significantly affected this traditional institute of the state. During the course of the military reform, there is considerable legislative activity regulating military service and a number of questions regarding the need to determine the legal status of military servicemen.

Servicemen along with the general legal status have a special status that not only complements the general, but also changes (limiting) him. Special status is determined by the totality of rights, freedoms, duties and responsibilities envisaged by the general, above all the Constitution, and special (military) legislation.

Human rights are defined and guaranteed by acts of international law: the Universal Declaration of Human Rights (1948) ${ }^{1}$; The International Covenant on Economic, Political, Social and Cultural Rights $(1966)^{2}$; The International Covenant on Civil and Political Rights (1966) and two optional protocols to the latter ${ }^{3}$; European Convention on Human Rights and Fundamental Freedoms (1950) and its Protocols ${ }^{4}$. These documents are the basis for any

${ }^{1}$ International Human Rights Standards // The Great Ukrainian Legal Encyclopedia: in 20 vols. / OV Petryshyn (ed.) Et al. 2017. Volume 3: The General Theory of Law. P. 294.

2 International Covenant on Economic, Social and Cultural Rights 1966 // Legal Encyclopedia: [in 6 volumes] / Ed. qty. Yu. S. Shemshuchenko (ed.) [And others]. Kiev : Ukrainian encyclopedia. M. Bazhana, 2001. Volume 3: K-M. 792 p.

3 International Covenant on Civil and Political Rights 1966 // Legal Encyclopedia: [in 6 volumes] / Ed. qty. Yu. S. Shemshuchenko (ed.) [And others]. Kiev: Ukrainian encyclopedia. M. Bazhana, 2001. Vol. 3: K-M. 792 p.

${ }^{4}$ Marmazov V.E. (2003) До питання про телеологічне (цільове) тлумачення Конвениії про захист прав і основних свобод людини [On the teleological (purposeful) interpretation of 
national legislation regulating the field of human rights and freedoms, including servicemen.

An important role in the regulation of the rights of servicemen is played by a group of international legal acts of direct action that determine the legal status of servicemen. These include, in particular, the acts that determine the rights of military servicemen in armed conflict - the Geneva Conventions of 1949 and their Additional Protocols, ratified by the USSR in $1954^{5}$.

Protecting and safeguarding the fundamental human rights of the citizens of one's own country is the main task of any country. Ukraine is no exception in this matter. However, the most regulated issues are the legal and social protection of military servicemen and the obligation to pay damages.

Before proceeding to the study of the problem posed to us, we must determine what is the "status" and what is the peculiarity of the "legal status of a serviceman".

E.O. Kharitonov notes, that one of the main issues of private law is the determination of the status of the individual, the regulation of his relations with society. It is no exaggeration to say that the categories "personality", "person", "subject of private law" are among the key concepts of private law, at a crucial points of which Guy emphasized in the second century".

As in all periods of the existence of law concept of "entity" included three features: social, legal and legal status, there are different approaches to the definition of "legal status".

It should be noted that the category "legal status" has recently appeared in legal scientific literature. Until the 1960s, Soviet scholars identified it with legal capacity; it was not regarded as a separate legal category. O. Skakun, explained the position of scientists of the era of socialism by saying that legal status and legal capacity arise and terminate in the subject at the same time, that they are equally inalienable, respectively, their similarity is the basis for identification ${ }^{7}$.

Over time and with the development of legal thought in the 1980s, the category of "legal status" began to be sufficiently developed in the theoretical and legal literature of the Soviet era, formulated as a problem and as one of

the Convention for the Protection of Human Rights and Fundamental Freedoms] Адвокат. 2003, № 6, 29-31.

Protection of War Victims // Legal Encyclopedia: [in 6 volumes] / ed. qty. Yu. S. Shemshuchenko (ed.) [And others]. Kiev: Ukrainian encyclopedia. MP Bazhan, 1998. Vol. 2: D - J. 744 p.

${ }^{6}$ Haritonov E.O, Haritonova O.I. (2019) Приватне право як концепт. Том III. Концепт приватного права $і$ рекодифікація иивільного законодавства в Украӥні: рефлексіі фронтиту: монографія [Private law as a concept. Volume III: The Concept of Private Law and the Recodification of Civil Law in Ukraine: Frontline Reflections: A Monograph] Odessa, Feniks.

${ }^{7}$ Skakun O.F. (2011) Theory of Law and State (3rd ed.) Kyiv, Alerta. 
the key concepts in the general theory of state and law, as well as in other fields legal science.

In the contemporary legal literature, the concept of "legal status" has not been unequivocal and continues to be debatable ${ }^{8}$.

\section{Characteristics of the legal status of the serviceman}

It is enshrined in the law that servicemen enjoy all the rights and freedoms of man and citizen, guarantees of these rights and freedoms ${ }^{9}$. Passing military service, on the one hand, realize right to the work, but on the other - carry out activities in the interest of the whole society, which stipulates the obligation of the state to ensure the realization of the rights of citizens entitled to them, and in the case of damage to the mainstream interests and non-material goods of the citizen (military serviceman) - the duty to guarantee his compensation.

The military official, as a distinguished subject, uses protection from the side of the state in compensation of damage, damage to his life and health.

The concept of status ("status") has a Latin origin and means status, position $^{10}$. [10] Using a variety of sources, let's look at some definitions of this word. Status - the legal position (set of rights and responsibilities) of a citizen or legal entity ${ }^{11}$.

Status - legal status, status. Status - legal status (set of rights and responsibilities) of a citizen. General legal status - the status of a person as a citizen of the state ${ }^{12}$.

The legal status of a serviceman is complex in its legal structure, in addition it has a two-part structure that includes civil and special units. Such separation is rather conditional, since both parts are interconnected and complementary. We believe that today there is a need to change the relationship and role of the structural elements of the legal status of a serviceman, if previously paramount were military service and duties, then now they should be organically combined with such categories as human rights, dignity, humanism, freedom, democracy, justice. All this requires a theoretical analysis in the interest of determining the legal status of military servicemen.

Special (branch) status determines the peculiarities of the situation of certain categories of citizens, provides the opportunity to perform their special functions.

8 Макаrchuk V.V. (2016) Теоретико-правовий дискурс щодо правового статусу реєстрового козацтва [Theoretical and Legal Discourse on the Legal Status of Registered Cossacks] Administrative law and process. № 2 (16). C.154-162.

${ }^{9}$ Constitution of Ukraine (1996). URL: http://zakon2.rada.gov.ua/laws/show/

${ }^{10}$ Marchuk V.P. (2003) Glossary of legal terms. Kyiv, MAUP.

${ }^{11}$ Volinka K.G. (2006) Explanatory Dictionary of State and Law Theory, Kyiv, Magistr.

${ }^{12}$ Kelman M.S. (2016) General theory of state and law, Kyiv, Kondor. 
Creation of special subjects of law is a natural process of differentiation of legal relations. Changing the sphere of legal regulation, complicating the mechanisms of regulation requires fixing on different categories of citizens certain, not peculiar to other subjects, rights and responsibilities.

Possession of the personality of a special subject of law is important for the legal regulation of his behavior, determination of his position in connection with the interaction with other subjects of law - the entry into certain legal relations ${ }^{13}$.

The servicemen - a person who is in the military service. Persons in military service are persons who are in the reserve for manning the Armed Forces of Ukraine and other military formations for a special period, as well as for carrying out the work of defense of the state. Reservists are persons who serve in the military reserve of the Armed Forces of Ukraine, other military formations and are intended for their recruitment in peacetime and wartime ${ }^{14}$.

Servicemen, from a legal point of view, persons who are with the state in public-legal relations and their activity in the army, in the navy, in institutions, departments and establishments of military and naval agencies, directly or indirectly contribute to the accomplishment of the tasks of defense and protection of the state.

Each servicemen is assigned a corresponding military rank. In military service and military rank, some servicemen may be superiors or subordinates to others. Servicemen who are not superior to other servicemen by their superiors or subordinates by their position and military rank may be senior or junior. All military servicemen take the military oath. Soldiers are personally responsible for protecting their homeland.

The status of servicemen is a set of rights and freedoms, duties and responsibilities of servicemen established by law.

The term "status of a serviceman" is equivalent to the term "legal status of a serviceman" and includes the whole complex of rights, freedoms and duties of a serviceman, formally defining his legal position in society. Foreigners and stateless persons who, in accordance with the law, serve in the Armed Forces of Ukraine by law are classified as servicemen. Citizens of Ukraine, foreigners and stateless persons who are serving in military service are servicemen ${ }^{15}$. Citizens acquire the status of military servicemen with the beginning of military service and lose with the end of military service

${ }^{13}$ Jarovska I.M. (2016) Сучасна теорія держави і права: традиційність та новаторство підходів [Contemporary State Theory and Law: Traditional and Innovative Approaches]. URL: http://nbuv.gov.ua/UJRN/vnulpurn_2016_837_43

${ }^{14}$ On the Armed Forces of Ukraine: Law of Ukraine (1992) URL: https://zakon.rada.gov.ua/ laws/show/1934-12

${ }^{15}$ Ibid. 
(it is retained also for servicemen taken captive, held hostage or interned). The nature of the status of a serviceman is determined by two interrelated factors: the possession of Ukrainian nationals and the military service. This implies that the civil rights and responsibilities of military servicemen may be somewhat limited in the interests of the service. At the same time, the status of the serviceman provides for certain compensations, guarantees and privileges for the servicemen. "The status of servicemen is a set of rights, freedoms guaranteed by the state, as well as the duties and responsibilities of servicemen established by the state".

The legal status of a serviceman is special and is exercised through the realization of possible and necessary rights and responsibilities through the processes of securing them; implementation; legal protection. In an emergency, the legal status of the serviceman has additional specificity. An emergency situation is a legal fact that gives rise to special legal relations between servicemen and the state - relations concerning additional guarantees in the form of privileges, compensations, allowances, additional payments.

For example, the participation of a serviceman in the JFO (Joint Forces Operation) in Eastern Ukraine.

The special status of a serviceman reflects the peculiarities of his/her position in relation to other categories of citizens. This position is influenced by the special nature of military service.

In addition, the special legal status of a serviceman consists of general (civilian) and military service units, with these units dialectically interacting with each other.

At the same time, the general legal status of servicemen is also of a special nature, since the legislation on this category of citizens establishes restrictions on certain constitutional rights and freedoms. Servicemen, reservists in the course of their duty in the military reserve, and employees of the Armed Forces of Ukraine may be restricted in their freedom of movement, free choice of residence and the right to freely leave the territory of Ukraine, the right to collect, use and impart information in accordance with the law ${ }^{16}$.

The specifics or peculiarities of the legal status of servicemen are determined by a number of factors, namely: first, a serviceman, being a citizen of his country, performs the duties of protecting citizens from criminal encroachments, which are connected with the necessity of unconditional fulfillment of the assigned tasks in any conditions of operational and combat situation, including those associated with risk to life. From this it follows that

\footnotetext{
${ }^{16}$ On the social and legal protection of servicemen and their families: Law of Ukraine (1992). URL: https://zakon.rada.gov.ua/laws/show/2011-12
} 
a serviceman as a citizen must be given the appropriate constitutional and administrative rights and responsibilities, be responsible.

Secondly, the rights and freedoms of servicemen are determined with a view to their ability to be exercised in military conditions, which entails some significant restrictions on rights and freedoms. They derive from the content of the military oath and the statutes of the Armed Forces of Ukraine.

Thirdly, the law stipulates and objectively justified restrictions on servicemen in their rights to work, freedom of speech, movement, rest, etc. are compensated by providing them with certain privileges and guarantees. Moreover, the approach to the establishment of the latter should be differentiated depending on the official position of the serviceman, the specifics of the service.

Fourth, military servicemen perform operational and combat tasks in difficult climatic and geographical conditions, day and night, any weather and any time of the year. All these circumstances make it necessary to grant military servicemen the right to various kinds of compensation.

Fifth, all military servicemen, in accordance with the military statutes, regardless of their military rank and position, are equal before the law and bear the responsibility established for the citizens, taking into account the peculiarities of its legal status ${ }^{17}$.

Thus, the legal status of a serviceman is special and can be defined as follows: the legal status of a serviceman is his special legal position in society and the state, determined by the system of special rights of the general, military legislation of rights, freedoms, duties and responsibilities.

\section{Specificity of civil legal status of a serviceman}

Recognizing each subject of law, the state establishes its legal status, provisions for the state, its bodies, other individuals and legal entities. Civil status of a serviceman is a set of rights, legitimate interests, the protection of which is guaranteed (guaranteed) by the state, as well as the duties of servicemen, which determines the limits of his participation in property and personal non-property relations. One part of the rights, legitimate interests and duties belongs to him as an individual, and the other is due to the specific situation.

These elements of the civil legal status of a serviceman are established by law, and their implementation is ensured by the forms and methods provided for by civil and civil procedural legislation. Consider, in more detail, some of the envisaged rights of military servicemen, taking into account the specifics.

\footnotetext{
${ }^{17}$ Basic V.P. (2000) Міжнародне гуманітарне право: Навчальний посібник [International Humanitarian Law: A Handbook Kiev : Worth.
} 
Of course, the right to life is of key importance for all human rights, since in its absence all other human rights and freedoms lose their significance. However, the legislator, while imposing on the serviceman the duty to protect the state, admits that there is a risk to his life. The presence of a "risk to life" in relation to a serviceman can be recognized as nothing more than a restriction on the right to life, since it is thus allowed that a person may lose his or her life in the performance of duties in the interests of the state. The logical consequence of the said "risk to life" is a similar restriction on the right to health, personal safety and integrity, which may also inevitably be violated by the "risk to life" permitted by the legislator.

A servicemen is guaranteed integrity and cannot be arrested except on the basis of a court order. In addition, a serviceman may not engage in tasks not provided for in his/her duties. The use of military servicemen to perform tasks other than military service is prohibited and entails liability under the law. Servicemen may be involved in the aftermath of accidents, catastrophes, natural disasters and in other cases only by decision of the Verkhovna Rada of Ukraine ${ }^{18}$.

During military service military pay is providing. The financial security is determined depending on the position, military rank, duration, intensity and conditions of military service, qualification, academic degree and academic rank of a serviceman. Cash and other types of security are stored for servicemen captured or held hostage, as well as interned in neutral states or missing persons. The families of the said servicemen are paid monthly security, including additional and other types of financial security, in the amount established by the serviceman on the day of his capture or hostage, internment in neutral states or unaccepted absence. For a special period in Ukraine, servicemen are not fined for defaulting on their credit obligations, as well as interest for using a loan. Based on the provisions of Articles 5, 6 of the Law of Ukraine "On the status of war veterans, guarantees of their social protection" of 22.10.1993 № 3551-XII, part 15 of Art. 14 of the Law of Ukraine "On social and legal protection of servicemen and their families" of 20.12.1991 № 2011-XII the Supreme Court concluded that the servicemen from the beginning to the end of the special period, and reservists and servicemen - from at the time of the call, during the mobilization and until the end of the special period, no penalties, penalties for failure to pay obligations to enterprises, institutions and organizations of all forms of ownership, including banks and individuals, as well as using a loan ${ }^{19}$.

18 Sitnyakivska S.M. Hlivnuk M.G. (2014) Соціальний та правовий захист військовослужбовців [Social and legal protection of military men]. URL: http://eprints.zu.edu.ua/ 23744/1/Ситняківська_С._Хливнюк_М..PDF

19 Statutes of the Armed Forces of Ukraine. URL: https://ifnmu.edu.ua/images/ studentam/pidgotovka_oficeriv_zapasu/statuti_zsu.pdf 
This paragraph does not apply to servicemen who have voluntarily surrendered. Also, one of the main aspects of state support for military servicemen is the right of military servicemen to health and medical care. The health protection of military servicemen is ensured by the creation of favorable sanitary and hygienic conditions for military service, life and a system of measures to limit the effects of dangerous factors of military service, taking into account its specificity and environmental conditions, which are carried out by commanders (chiefs) in cooperation with local authorities, local self-government bodies ${ }^{20}$.

Also, the Law of Ukraine "On Social and Legal Protection of Servicemen and Members of Their Families" regulates the issues of ensuring their rights and freedoms, social and legal protection of servicemen, their families and limiting certain rights in connection with the performance of their military service duties, and exactly:

- servicemen have the right to participate in elections, to be elected to councils of all levels, to participate in national and local referendums; at the same time, servicemen cannot be members of any political parties, movements, organize and conduct strikes; freedom of conscience and the right to freely satisfy one's religious needs are guaranteed; freedom of scientific, technical and artistic creativity is guaranteed; military servicemen may not engage in entrepreneurial activity, but, at the same time, the state guarantees them material and other security in the amount that stimulates interest in military service (namely: financial, material security);

- same law defines the procedure for exercising the right of military servicemen to rest, namely: length of working day and distribution of working time; the procedure for providing basic and additional holidays; provision of free health care and spa treatment and rest;

- law defines the procedure for providing servicemen with accommodation: before receiving permanent accommodation, servicemen must be provided with service accommodation; servicemen are paid monetary compensation for temporary renting (hiring) of housing;

- law also provides for the right to education: servicemen are allowed to study at other educational establishments without interruption of service in the manner stipulated by the Regulation on passage of military service to the Armed Forces of Ukraine by citizens of Ukraine and the right to free travel of a serviceman and his family on leave within Ukraine, when transferred to a new place of service, to a place of residence when released from military service within Ukraine.

20 Sitnyakivska S.M. Hlivnuk M.G. (2014) Соціальний та правовий захист військовослужбовців [Social and legal protection of military men]. URL: http://eprints.zu.edu.ua/23744/1/Ситняківська_C._Хливнюк_М..PDF 
This law provides for pension provision for military servicemen, establishes that the time of stay of citizens of Ukraine in military service is credited to their insurance experience, seniority of work in the specialty, as well as to the experience of public service. It should be noted that the legal norms concerning the rights of servicemen, social protection issues are duplicated in other laws that regulate the order of creation and activity of military formations in Ukraine. Thus, the Law of Ukraine "On the Armed Forces of Ukraine" contains Article 16 "Social and legal protection of servicemen, their families and employees of the Armed Forces of Ukraine", which in fact duplicates the legal provisions of the Law of Ukraine "On social and legal protection of servicemen and their families" 21 .

\section{Ensuring the legal status of the serviceman}

Legislation establishes additional rights (privileges, compensation, social and legal guarantees) for servicemen who also characterize their general legal status as special. Military service rights are related to the enlistment of military servicemen and the passage of service. They are divided into general, official and special.

Common military service rights are the rights enjoyed by all servicemen, which are connected with the passage of the last military service and are intended to indirectly ensure the effectiveness of their activities through the implementation of moral and material incentives: in the general group of military service rights can be distinguished by which: a) promotion (career); b) state financial support; c) the right to protection; d) benefits; e) incentives.

Another structural element of the legal status of a serviceman is the established legal responsibility, the Law of Ukraine "On Military Duty and Military Service" 22 and the Statutes of the Armed Forces of Ukraine ${ }^{23}$. Depending on the nature and gravity of the offense, servicemen are involved in the following types of legal responsibility: disciplinary, administrative, material, civil and criminal $^{24}$. Responsibility should be understood to mean

21 Pashinsky, V.Y. (2013) Правове регулювання соціального і правового захисту військовослужбовців в Україні [Legal regulation of social and legal protection of military personnel in Ukraine] Law Science.

${ }^{22}$ On Military Duty and Military Service: Law of Ukraine. Bulletin of the Verkhovna Rada of Ukraine (BB). 1992. No. 27. Article 385.

${ }^{23}$ Statutes of the Armed Forces of Ukraine. URL: https://ifnmu.edu.ua/images/studentam/ pidgotovka_oficeriv_zapasu/statuti_zsu.pdf

${ }^{24}$ Borisova V.I., Spasibo-Fateeva I.V., Yarotskiy V.L. (2011) Civil law (2nd ed.) Retrieved from URL: http:// uristinfo.net/2010-12-27-04-58-59/264-tsivilne-pravot1-viborisova-ta-in.html; Borisenko V. (1994) Особенности уголовной ответственности военнослужащих [Features of criminal liability of military personnel] Retrieved from URL: https://juristlib.ru/book_1994.html; Holodkov I.V. (1999) Право военнослужащих на защиту своих прав, свобод и законных 
the duty of a serviceman to be punished for an offense that may be expressed in restrictions of a personal, property or organizational nature. The legal responsibility of military servicemen has its own specific features related to the special nature of military service.

Ensuring the legal status of a serviceman is the activity of public authorities, military administration bodies and officials to create the conditions (guarantees) for the lawful and steady implementation of it and legal protection. The realization of the legal status is a process of materialization of the rights and duties of a serviceman, in the course of which he receives a benefit that constitutes the content of a specific subjective right with the fulfillment of a socially necessary, established norm of law, duty.

Legal protection is understood as an element of the exercise of the legal status of a serviceman whose content is the activity of the state, military authorities, commanders and commanders, and the military serviceman himself/herself to create legal conditions conducive to stopping the process of exercising his/her rights and duties (protection of rights), and in in case of violation, resumption of this process (protection of rights). Thus, an institution of legal protection enters into force only when there is a threat to the process of realization of the legal status or it is interrupted for any reason. Ensuring the legal status of a serviceman is a legal duty of the state.

Guarantees of the legal status of a serviceman are general conditions and special (legal) means that create him/her actual opportunity to enjoy the rights and obligations, satisfy the interests and securely protect them. In this case, all guarantees are divided into general and legal.

General guarantees are objective material and spiritual conditions for exercising the rights and responsibilities of a serviceman. It should be noted that the components of general safeguards are the following: economic, political, social and spiritual.

Legal guarantees of the legal status of a serviceman are a system of interrelated ways and means (normative, institutional and procedural) that ensure the proper recognition, realization of rights and duties of a serviceman and their legal protection. Legal guarantees of the rights, duties and responsibilities of servicemen are expressed, first and foremost, in the norms of the legislation, which disclose and specify the constitutional rights and obligations, and also establish the procedure for their exercise;

Legal guarantees of the legal status of a serviceman include such types as: 1) guarantees of realization of rights and duties; 2) guarantees of legal

\footnotetext{
интересов в сфере военно -административных отношений [The right of military personnel to protect their rights, freedoms and legitimate interests in the field of military - administrative relations] Retrieved from URL: https://juristlib.ru/book_1216.html
} 
protection of the rights and duties of the serviceman (protection, protection and legal assistance); 3) organizational (service) guarantees;

Legislation includes the following legal guarantees for the exercise of the rights and duties of a serviceman: the obligation to fulfill the legal requirements of servicemen; circumstances that exclude the criminality of the serviceman; inadmissibility of interference in the official activity of a serviceman; guarantees of personal security of the armed serviceman; guarantees of personal safety of servicemen and their families.

The legislator enshrined the following guarantees for the legal protection of a serviceman: the right of a serviceman to judicial protection; supervision over observance of rights and duties of the serviceman; the activities of the Ombudsman; legal assistance to servicemen; protection of the rights of military personnel by public associations; self-defense; responsibility of citizens and officials guilty of violating the rights of servicemen and preventing them from performing their duties.

Organizational guarantees of the legal status of the military may be norms that establish the need; making managerial decisions aimed at securing the rights of a serviceman as a person; issuing orders on issues related to providing social guarantees for family members; improving the style of work of military management bodies; raising the level of service, staff and legal culture of military personnel, developing and implementing a program to increase the legal knowledge of the personnel of units and units of troops, etc.

An emergency situation is defined as a set of conditions and circumstances that have arisen as a result of objective or subjective factors that have caused negative consequences for the object of influence that have resulted in the death of people, significant damage to property of citizens, legal entities and the state, environmental damage equilibrium, normal functioning of the lifesupport system, threats to the constitutional order and security of the state, requiring the introduction of special legal regulation and immediate actions involving external forces in relation to the object and means. In the event of an emergency, servicemen require additional, qualitatively and quantitatively other legal guarantees of their legal status, designed to compensate for the increased risk to life, difficulties and poverty associated with the performance of military duty in such circumstances.

According to the type of emergency situation, a group of additional guarantees is also defined: a) additional guarantees of legal status of a serviceman during the period of military service; b) additional guarantees for the period of Emergency; c) additional guarantees for the timing of tasks in the context of non-international armed conflict; d) additional guarantees for the time of participation and fight against terrorism; e) additional guarantees in the course of completing tasks in the territory after the completion of large-scale military operations. 
For example, one of the types of emergencies can be attributed to JFO (Joint Forces Operation) in Eastern Ukraine.

In terms of the content of the guaranteed subjective right, the following groups of additional guarantees should be distinguished: a) additional guarantees for the exercise of the constitutional right of a serviceman to remuneration for work without any discrimination; b) additional guarantees of the right of the serviceman to social security by age, in case of illness and disability; c) additional guarantees of the right of the serviceman to rest; d) additional guarantees for the right of the serviceman to housing.

Depending on the legal form of the guarantee, the following additional guarantees are allocated: a) benefits; b) compensation; c) additional payments; d) benefits.

By the nature of the legal rules that ensure the legal status: a) substantive law; b) procedural and legal.

Also, it should be noted that the study of regulations and scientific literature showed that, depending on the circumstances, the grounds for the division of additional legal guarantees for types may be the following: 1) the legal force of the normative legal act; 2) type of emergency; 3) the content of the guaranteed subjective right of the serviceman; 4) legal form of guarantee; 5) the nature of the legal provisions that ensure legal status.

Depending on the legal force of the regulatory act, additional guarantees are divided into a) the guarantees provided by law and b) the guarantees established by the by-laws.

\section{CONCLUSIONS}

Summarizing the above, we can draw the following conclusion. Protection of the homeland is the responsibility of the citizen of Ukraine. Defense of the country is one of the permanent functions of the state, the presence of its own army and other armed formations is usually considered an important feature of the state.

The population is objectively distinguished by a special, fairly large group of people carrying on military service. From this, in turn, functionally follows the existence of a special legal status. By its nature, this type of activity is objectively related to certain sufferings, burdens, but this does not mean that the subjective rights of a given social group lose their fundamental importance or are relegated to the background.

Thus, the legal status of a serviceman is special and can be defined as follows: the legal status of a serviceman is his special legal position in society and the state, determined by the system of special rights of the general, military legislation of rights, freedoms, duties and responsibilities.

In addition, the legal status of military personnel is characterized by a large number of restrictions on universal (constitutional) rights and freedoms. 
Regulatory acts not only establish the specific rights of military personnel, but also modify the effect of universal human rights and freedoms of military personnel in the context of their professional duties. In view of this, we consider it necessary to carry out work on the regulation of normative acts of both military legislation and legislation in different fields of law, which will allow: to eliminate the existing contradictions, gaps of the current legislation; abolish obsolete rules of law.

\section{SUMMARY}

The study of the civil status of military servicemen is of scientific and practical interest, given the specifics of military service, since this category of citizens cannot be fully protected from the negative consequences of performing their official duties. It is important to create conditions for the continued exercise of military rights by military personnel, while excluding any restrictions other than those provided for by law. At the same time, existing regulations which should regulate social relations involving servicemen differ to some inconsistency, which reduces the efficiency of their use. The purpose of the study is to clarify the issue of analysis of legislation on the legal and civil status of military servicemen. The object of the study is the public relations that are formed in connection with the determination of the peculiarities of the civil status of servicemen. The subject of the research is the definition of the civil status of servicemen and normative legal acts that establish the peculiarities of civil law status of servicemen. The methodological basis of the study is dialectical, historical, formal-logical, system-critical, statistical and other methods. Therefore, in the current context, it is necessary to develop a new concept of ensuring the subjective rights of servicemen based on the rule of human rights in the performance of military duty. Under the civil legal status of a serviceman should determine the set of rights and legitimate interests, the protection of which is guaranteed (guaranteed) by the state, as well as the duties of servicemen, which determines the limits of his participation in property and personal nonproperty relations. One part of the rights, legitimate interests and duties belongs to him as an individual, and the other is conditioned by the specifics of his position. Elements of civil legal status of a serviceman are established by law, and their implementation is ensured by the forms and methods provided by civil and civil procedural legislation. Most of the previously formulated scientific provisions are based on fundamentally different approaches to Soviet law than modern ones. Although they remain of some importance, they still need to be rethought in the light of new perceptions of the status of servicemen. Which confirms the need to eliminate the legal and factual obstacles to the implementation by military personnel of their full subjective rights and responsibilities. 


\section{REFERENCES}

1. International Human Rights Standards // The Great Ukrainian Legal Encyclopedia: in 20 vols./OV Petryshyn (ed.) Et al. 2017.Volume 3: The General Theory of Law. P. 294.

2. International Covenant on Economic, Social and Cultural Rights (1966) // Legal Encyclopedia: [in 6 volumes]/Ed. qty. Yu. S. Shemshuchenko (ed.) [And others] K.: Ukrainian encyclopedia. M. Bazhana, 2001. Volume 3: K - M. 792 p.

3. Marmazov V.E. (2003) До питання про телеологічне (цільове) тлумачення Конвенції про захист прав і основних свобод людини. Адвокат. 2003. № 6. С. 29-31.

4. Protection of War Victims // Legal Encyclopedia: [in 6 volumes]/ed. qty. Yu. S. Shemshuchenko (ed.) [And others]. K.: Ukrainian encyclopedia. MP Bazhan, 1998. Vol. 2: D - J. 744 p.

5. Haritonov E.O, Haritonova O.I. (2019) Приватне право як концепт. Том ІІІ.Концепт приватного права i рекодифікація цивільного законодавства в Україні: рефлексії фронтиту: монографія. Odessa, Feniks.

6. Skakun O.F. (2011) Theory of Law and State (3rd ed.) Kyiv, Alerta.

7. Макаrchuk V.V. (2016) Теоретико-правовий дискурс щодо правового статусу реєстрового козацтва. Administrative law and process. № 2 (16). C. 154-162.

8. Constitution of Ukraine (1996). URL: http://zakon2.rada.gov.ua/ laws/show/

9. Marchuk V.P. (2003) Glossary of legal terms. Kyiv. MAUP

10. Volinka K.G. (2006) Explanatory Dictionary of State and Law Theory. Kyiv. Magistr.

11. Kelman M.S. (2016) General theory of state and law. Kyiv. Kondor.

12. Jarovska I.M. (2016) Сучасна теорія держави i права: традиційність та новаторство підходів. URL: http://nbuv.gov.ua/ UJRN/vnulpurn_2016_837_43

13. On the Armed Forces of Ukraine: Law of Ukraine (1992). URL: https://zakon.rada.gov.ua/laws/show/1934-12

14. On the social and legal protection of servicemen and their families: Law of Ukraine (1992). URL: https://zakon.rada.gov.ua/laws/show/2011-12

15. Basic V.P. (2000) Міжнародне гуманітарне право: Навчальний посібник. A Handbook. K.: Worth

16. Sitnyakivska S.M., Hlivnuk M.G. (2014) Соціальний та правовий захист військовослужбовців. URL: http://eprints.zu.edu.ua/23744/1/ Ситняківська_С._Хливнюк_M..PDF

17. Statutes of the Armed Forces of Ukraine. URL: https://ifnmu.edu.ua/ images/studentam/pidgotovka_oficeriv_zapasu/statuti_zsu.pdf 
18. Pashinsky, V.Y. (2013) Правове регулювання соціального i правового захисту військовослужбовців в Україні. Law Science.

19. On Military Duty and Military Service: Law of Ukraine. Bulletin of the Verkhovna Rada of Ukraine (BB). 1992. No. 27. Article 385.

20. Statutes of the Armed Forces of Ukraine. URL: https://ifnmu.edu.ua/ images/studentam/pidgotovka_oficeriv_zapasu/statuti_zsu.pdf

21. Borisova V.I., Spasibo-Fateeva I.V., Yarotskiy V.L. (2011) Civil law (2nd ed.). URL: http://uristinfo.net/2010-12-27-04-58-59/264-tsivilnepravot1-viborisova-ta-in.html

22. Borisenko V. (1994) Особенности уголовной ответственности военнослужащих. URL: https://juristlib.ru/book_1994.html;

23. Holodkov I.V. (1999) Право военнослужащих на защиту своих прав, свобод и законных интересов в сфере военно-административных отношений. URL: https://juristlib.ru/book_1216.html

Information about the author: Kryvenko Yu. V., Candidate of Legal Sciences, Departament of Civil Law National University “Odesa Academy of Law" Fontan road 23, Odesa, Ukraine ORCID: https://orcid.org/0000-0001-7506-0786 